\title{
and Health (ICASSETH 2019) Improving Work Productivity Through the Improvement of Organizational Atmosphere and Culture
}

\author{
Ipong Dekawati* \\ Graduate Program \\ Wiralodra University Indramayu \\ Indramayu, Indonesia \\ *ipongdekawati@unwir.ac.id
}

\begin{abstract}
In University institutions, the work productivity of educational staff should be highly improved to support the implementation of three main obligations of higher education. This study only focuses on discussing organizational atmosphere and culture. This study used quantitative approach method. The data were collected through direct observation, random interviews with the dean, the head of administration and staff. The questionnaires were distributed to 56 educational staff. Simple random sampling with Slovin formulas was conducted to determine the total of the sample. The data were analysed by using regression analysis technique. F-test was used as a significant test. The result showed that: work productivity can be improved through the improvement of organizational atmosphere and culture. Based on the result of the research, it is suggested that (1) fair appreciation and proportional should be given to the administration staff, firmly with the commitment to support the staff trust so it creates a conducive working atmosphere. (2) to give more attention to team performance, build work discipline, strengthen relationships better working synergy, better teamwork, so the organizational culture can support work productivity.
\end{abstract}

Keywords: organizational atmosphere, organizational culture, work productivity

\section{INTRODUCTION}

The information received, related to the quality of higher education stated that the rank of higher education in Indonesia is confirmed very poor, compared to neighbouring countries [1]. Especially when it is compared to the condition of higher education in western developed countries. Certainly that the quality of education is in line with the progress of the nation. Therefore, the condition of education describes the condition of education itself. The lagging quality of education clearly illustrates the condition of Indonesia's progress at the international level. The government has been trying to improve the quality of higher education, one of the efforts is rector recruitment program from other countries that can support the acceleration of quality improvement of higher education.

The progress of education is simply seen in the curriculum, facility, and human resources. The human resources in higher education are educators and educational staff. The urgency of educators and educational staff existence cannot be ignored. Educators are educational staff who are qualified as teachers, lecturers, counsellors, tutors, instructors, facilitators, and other designations by following their specialties and participate in organizing education. While educational staff are members of the community who devote themselves and are appointed to support the implementation of education [2].

The educational staff is a supporting element in organizing education. Whereas, the educational staff is one element in educational management. It can be understood that the productivity of educational staff tends to influence the quality of the education unit. The task of the educational staff is as stipulated in UUSPN No. 20/2003 Article 39 is to carry out administration, management, development, supervision, and technical services to support the education process in the education unit. The work productivity of educational staff is needed. Related to the work productivity of educational staff in private tertiary institutions is still a big question, especially regarding the target of completion in terms of quantity, work results seen from the quality and sufficient time to carry out the work assigned. The target of the workforce productivity of education staff in higher education units can be achieved because when the supporting factors have been increasingly conducive. Empirical conditions show that starting from the experience of working in several educational institutions. Especially in private universities, it is difficult to increase work productivity, both educators (lecturers) and education staff (staff). The Cases of work not being completed on time, as well as the number and quality of work results that are not yet as expected, and there is no measure for future improvements (less futuristic). The pattern of staff behaviour, especially regarding work discipline, is still weak

The higher education unit is an educational organization. Therefore, other factors that are thought to influence work productivity are the organizational atmosphere and culture. Organizational atmosphere factors are believed to tend to affect productivity. The conditions of organizational relationships and interactions as well as relationships between individuals play a role in influencing the work productivity of members of the organization. This condition was shown by Yusuf research results, "the work atmosphere factors of school organizations 
contribute individually and significantly to the teacher work productivity factors" [3]. Research results "there is a significant influence of the work atmosphere on teacher productivity" [4]. Research results "there is a positive and significant relationship between work atmosphere with teacher productivity" [5].

The lack of harmony between staff can lead to a reluctance of someone to come to work, which can be a gap in work relationships. The organizational atmosphere in the workplace that lasts a long time occurs in an institution, over time will shape the culture of the organization. Good working atmosphere and vice versa. Organizational culture can encourage or even be counter-productive to productivity, depending on habits in carrying out long-standing work so that it becomes a culture that tends to be conducive or vice versa.

Educational institutions, especially higher education are expected to become pioneers in the advancement of science and technology. Therefore, before looking at the conditions of work productivity in other sectors, it is deemed necessary to know the conditions of work productivity of educational staff at tertiary institutions. Based on the explanation above, the focus of the research is on how to increase the work productivity of education staff through organizational atmosphere and culture?

\section{ATMOSPHERE AND CULTURE ORGANIZATION AND WORK PRODUCTIVITY}

Related to work atmosphere according to Davis can be interpreted as a human environment in which workers or organizations do work and its existence is something that cannot be touched or seen but exists [6]. While Stringer describes the work atmosphere in organizations with the concept of everything contained in the work environment, which is felt directly or indirectly by people who are different in the environment [7]. Meanwhile, Siagian explained that organizational atmosphere as work conditions that are physical and non-physical in the work environment that also influences behaviour and becomes a motivational factor that needs attention from every leader in the organization [8]. On the other hand, Liliweri defines the organizational atmosphere as patterns of behaviour, attitudes, and feelings that are displayed repeatedly which serve as characteristics of organizational life [9]. As Stringer, highlighting the problem of its characteristics that the characteristics or dimensions of the organizational atmosphere affect the motivation of organizational members to behave [7]. To measure organizational atmosphere, there are 6 dimensions needed, namely: (1) Structure; (2) Standards; (3) Responsibilities; (4) Award (recognition); (5) Support; and (6) Commitment.

Organizational culture is a shared meaning that can influence the thoughts, feelings, and actions of the people involved in the organization concerned. Because organizational culture can affect feelings and thoughts, it certainly can affect the perceptions, views, and workings of its members. Concerning organizations, "culture is a set of values, beliefs, and understanding of the importance shared by its members" [10]. Organizational culture is "a system of shared meanings shared by members that distinguish the organization from other organizations" [11]. Organizational culture is "The system of shared values, beliefs, and habits within an organization that interacts with the formal structure to produce behaviour norms" [12]. Organizational culture as a fictitious framework consisting of attitudes, values, norms of behaviour and expectations that are shared by organizational members. The root of each organizational culture is a set of core characteristics that are valued collectively by members of the organization" [13]. Meanwhile, Gibson et al provides an understanding of organizational culture" as what workers feel and how this perception creates patterns of beliefs, values , and expectations [14]. "Still according to Gibson et al that" organizational culture contains a mixture of values, beliefs, perceptions, norms of sincerity and behaviour patterns" [14]. Which is very important from organizational culture (strong culture, suitable culture, and adaptive culture) to organizational effectiveness is reasonable, therefore, it can be assumed that organizational culture will have a major influence on the behaviour of members which means it will also affect the organization's products and services.

The definitions above show that organizational culture is a system of values, beliefs, habits, and actions that are the basic common assumptions that form the norms of behaviour of members to achieve organizational goals. The behavioural norms of the members of the organization will distinguish the organization from other organizations. Because organizational culture is what distinguishes one organization from another, then organizational culture has characteristics. "Ten characteristics of organizational culture [15], including: (1) observe behaviour: language, customs, traditions; (2) groups norms: standards and values; (3) exposed values: published, publicly announced values; (4) formal philosophy: mission; (5) rules of the game: rules to all in organization; (6) atmosphere: atmosphere of group in interaction; (7) embedded skills; (8) habits of thinking, acting, paradigms: shared knowledge for socialization; (9) shared meanings of the group; and (10) metaphors or symbols. Luthans presents six important characteristics of organizational culture [16], namely: (1) observed behavioural regularities; that is, the order in which the members act as they seem to be observed. When members interact with other members of the organization, they may use certain common language, terms, or rituals; (2) norms; that is, the various standards of behaviour that exist, including guidelines regarding the extent to which a job must be done; (3) dominant values; namely the existence of core values shared by all members of the organization, for example regarding high product quality, low absenteeism or high efficiency; (4) philosophy; namely the existence of policies relating to the confidence of the organization in treating customers and staffs; (5) rules; namely the existence of strict guidelines, related to organizational progress (6) organization atmosphere; is an overall feeling (an overall "feeling") which is described and conveyed through spatial conditions, the way interacts by members of the organization and the way members of the organization treat themselves, customers or others.

Ten important characteristics can be used as essential references in understanding and measuring the existence of organizational culture [11] cited from Pabundu [17]: (1) Individual Initiative. This is the level of responsibility, freedom or independence that each individual has in expressing his 
opinion. (2) Tolerance of Risk Actions. In organizational culture, it needs to be emphasized, the extent to which staff is encouraged to be able to act aggressively, innovative and take risks. (3) Direction. The extent to which an organization can create the desired goals and expectations. (4) Integration. Integration is intended to the extent to which an organization can encourage organizational units to work in a coordinated manner. (5) Management Support. The extent to which managers can provide communication or direction, clear assistance, and support for subordinates. Management attention to staff is very helpful for the smooth performance of an organization. (6) Tool Control. Regulations or norms that apply in an organization. For this reason, some regulations and supervisors (direct superiors) are needed that can be used to monitor and control staff behaviour in an organization. (7) Identity. The extent to which staff in an organization can identify themselves as a whole and not as a particular workgroup. (8) Rewards System. The extent to which the allocation of rewards (such as salary increases, promotions and so on) is based on staff performance, not seniority or favouritism. (9) Tolerance. Tolerance of Conflict The extent to which staffs are encouraged to express conflict and criticism openly. (10) Communication Patterns. The extent to which communication is limited by formal hierarchies of authority. Sometimes the hierarchy of authority can inhibit communication patterns between superiors and subordinates or between staff themselves. To make it easier in the research process by not ignoring the meaning of this research. Then the dimensions for organizational culture in this study adopt the opinion of Gibson et al [14], namely: (1) Trust, (2) Perception, (3) Norms, (4) Peculiarities, and (5) Behavioural patterns.

Related to work productivity, according to the National Productivity Council [18], is 'mental attitude that has a view of the quality of life today must be better than yesterday and tomorrow better than today'. Labour productivity is "a comparison between the work results achieved with the participation of labour unity of time" [19]. Work productivity is a measure that shows the consideration between the input and output issued by an organization or company and the role of labour which is owned by time union [20]. Productivity is "the ability to obtain the maximum benefit from the facilities and infrastructure available by producing optimal output even if possible to the maximum" [8]. "Productivity is a comparison between the work in the form of goods or services with the source of energy used in a production process" [21]. Sinungan states the notion of productivity [22] as follows: (1) The traditional formula for overall production is nothing but the ratio of what is produced (output) to the entire production equipment used. (2) Productivity is a mental attitude that always has the view that the quality of life today is better than yesterday. (3) Productivity is a harmonious integrated interaction and three essential factors, namely: Investment including knowledge and technology as well as research, management and labour. Productivity is "the ability of a set of economic resources to produce something or as a comparison between sacrifice (input) with income (output). Productivity is the ratio between output and input, this formulation applies to the company, industry and the economy as a whole" [23]. Commonly, productivity is "a scientific comparison between the amount produced and the amount of each resource used during the process" [24].

As the other dimensions, work productivity is also influenced by various factors. Mangkuprawira states that "factors that influence productivity are relatively complex, can be intrinsic factors (level of education, knowledge, skills, motivation, health, and experience) and can be extrinsic factors (salary/wages) work environment, leadership, facilities work, and social relations) [25]. Several factors that affect work productivity, in general, there are eight factors [22], namely: (1) Human needs which include: quantity, level of expertise, cultural and educational background, abilities, attitudes, interests, structure occupation, expertise and age (sometimes gender) of the workforce. (2) Capital consisting of fixed capital (machinery, buildings, tools, volume and structure standards) and raw materials (volume and standards). (3) Methods or processes including task space, handling of auxiliary raw materials and machinery, production planning and supervision, maintenance through prevention, technology using alternative methods. (4) The production which includes: quantity, quality, production room, mixed structure, and production specials. (5) Organizational environment (internal) in the form of organization and planning, management systems, working conditions (physical), work atmosphere (social), corporate objectives and their relationship with environmental objectives, incentive systems, personnel policies, leadership style and company size (economies of scale). (6) State (external) environment such as economic conditions and trade social and political structure, politics, industrial structure, long-term development goals. Recognition or endorsement, government economic policies (taxation and others). (7) International (regional) environment consisting of conditions of world trade, international trade issues of international specialization, labour migration policies, and labour standards. (8) Feedback, i.e. information that has to do with reciprocal input and output within the company, between the company and the scope of the country (international).

Simamora explains that the factors used in the measurement of work productivity include work quantity, work quality, and timeliness [26]. In this study, researchers measured work productivity by using indicators such as work quantity, work quality, and timeliness. Referring to the opinion of Busro [27], to calculate productivity can be done by looking at the amount of labour, the number of variable costs used, time of work, quality of goods/services, and prices of goods and services produced. Furthermore, Busro adds that the productivity measure is based on the quality of output produced, the quantity of output of products or goods/services, and the measure of company progress (in this research is interpreted by institutions) for the long term in the form of marketing networks [29]. So it can be summarized that to measure productivity can be used dimensions: (1) Number of staffs involved; (2) Time needed; (3) The number of goods/services produced; (4) Quality of goods/services produced; and (5) Measure of progress. 


\section{RESEARCH METHODOLOGY}

Quantitative approach was used in this study. To collect the data, direct observation and random interview with the dean, head of administration and staff were conducted to see the situation and operational condition. Likert scale closed and structured questionnaire was distributed to 56 staff. These questionnaires were provided with five alternative answers with the range 1-5. These alternative answers were provided for all variables; Strongly Agree (SA), Agree (B), Neither Agree (NA), Disagree (DA), and Strongly Disagree (SDA). The simple random sampling technique with a Slovin formula was used to determine the sample. The data were analysed with the regression analysis technique and F-test was used as a significant test.

\section{RESULTS AND DISCUSSION}

The questionnaire collected was selected to see the validity and completeness of the answers submitted. All collected questionnaires have been analysed and meet the requirements for calculation. The following table shows the condition of the organization's atmosphere, organizational culture, and work productivity according to respondents' assessments submitted through a questionnaire.

TABLE I. THE ORGANIZATIONAL ATMOSPHERE CONDITION

\begin{tabular}{|l|l|l|}
\hline \multicolumn{1}{|c|}{ Dimension } & \multicolumn{1}{c|}{ Score } & \multicolumn{1}{c|}{ Criteria } \\
\hline Structure & 3,83 & Good \\
\hline Standard & 3,61 & Good \\
\hline Responsible & 3,08 & Good \\
\hline Appreciation & 2,41 & Fair \\
\hline Support & 4,12 & Very Good \\
\hline Commitment & 2,96 & Fair \\
\hline Motivator function & 4,01 & Very Good \\
\hline
\end{tabular}

There are two dimensions of organizational atmosphere variables that are considered not good. Namely the dimensions of appreciation and commitment. Staff or education staff feel that management still lacks respect for their work. In addition to the lack of appreciation for staff, staff development is still far from expectations. Likewise, with compensation that is considered not balanced with the dedication they give to the institution. On the commitment side, institutions are also still low, for example in terms of clarity of tasks and work, and commitments with the staff are not completely implemented.

TABLE II. ThE CONDITION OF ORGANIZATIONAL CULTURE

\begin{tabular}{|l|l|l|}
\hline \multicolumn{1}{|c|}{ Dimension } & \multicolumn{1}{c|}{ Score } & \multicolumn{1}{c|}{ Criteria } \\
\hline Trust & 4,02 & Very Good \\
\hline Perception & 2,98 & Fair \\
\hline Norm & 4,26 & Very Good \\
\hline Specificity & 4,04 & Very Good \\
\hline Behavior pattern & 2,99 & Fair \\
\hline
\end{tabular}

Dimensions of trust, norms, and specificities are very good. While the dimension of perception in which it involves cooperation, efficiency, and effectiveness according to respondents' assessment is still low with a score below 3.0. Behavioural dimensions concerning discipline, cleanliness, and friendliness also scored less than 3.0. Of course, both dimensions need special attention to be improved.

TABLE III. The CONDITION OF Work PRODUCTIVITY

\begin{tabular}{|l|l|l|}
\hline \multicolumn{1}{|c|}{ Dimension } & \multicolumn{1}{c|}{ Score } & \multicolumn{1}{c|}{ Criteria } \\
\hline Staff involvement & 3,92 & Good \\
\hline Time required & 2,98 & Fair \\
\hline Quantity of work & 2,95 & Fair \\
\hline Quality of work & 2,96 & Fair \\
\hline Progress measurement & 3,88 & Good \\
\hline
\end{tabular}

Only two dimensions that the condition of work productivity is good, and the others are low staff achievement It showed an imbalance of work performance (busy with work and lazy). Even though the conditions are good, it can still be improved to a very good stage.

All statistical calculations are assisted with SPSS Version 22. The table is not shown here, but the required numeric data is written about the calculation results table. To find out the magnitude of the influence of the organizational atmosphere individually (partial) on work productivity is taken from the value of $t$ on the calculation of Coefficients with testing criteria if the level of significance is less than 0.05. Based on the t-test results table, it is obtained that the t-count value of the organizational atmosphere variable has a value of $p$-value $0,000<0.05$ which means that it has a significant distribution. This means that the organizational atmosphere partially influences work productivity. Regression equation $\mathrm{y}=\mathrm{a} \mathrm{bx}_{1}$ from the calculation results obtained $\mathrm{y}=50.543+0.254 \mathrm{X}_{1}$. A constant of 50.543 states that if there is an increase in the value of the organizational atmosphere variable, then work productivity is 50.543. The regression coefficient of 0.254 states that every change of one score or atmosphere value of the organization will give a score of 0.254 .

Furthermore, to find out the magnitude of the influence of organizational atmosphere on work productivity taken from the calculation of the coefficient of determination, that $\mathrm{R}$ Square of 0.082 , this means that the coefficient of determination (KD) $=$ $\mathrm{R}^{2} \mathrm{X} 100 \%$ or $0.082 \mathrm{X} 100 \%=8.2 \%$ work productivity is influenced by organizational atmosphere variables, while the remaining $91.8 \%$ is influenced by other factors not examined. To find out the magnitude of the influence of organizational culture individually (partial) on work productivity is taken from the value of $t$ in the Coefficients table with the criteria for testing the significance level of less than 0.05. Based on the ttest results obtained that the t-count value of organizational culture variables has a value of $p$-value $0,000<0.05$ meaning significant. Thus the organizational culture partially influences work productivity. Regression equation $\mathrm{y}=\mathrm{a} \mathrm{bx} \mathrm{b}_{2}$ from the calculation results obtained $y=55,641+0,165 X_{2}$. A constant of 55,641 states that if there is an increase in the value of the organizational culture variable, then work productivity is 55,641. The regression coefficient of 0.165 states that every change of one score or organizational culture will give a score of 0.165 .

Furthermore, to find out the magnitude of the influence of organizational culture on work productivity can be seen from the calculation of the coefficient of determination, that $\mathrm{R}$ Square is 0.062 , this means that the coefficient of 
determination $(\mathrm{KD})=\mathrm{R}^{2} \mathrm{X} 100 \%$ or $0.062 \times 100 \%=6.2 \%$ work productivity influenced by organizational culture variables, while the remaining $93.8 \%$ is influenced by other factors not examined. "There is a very significant positive relationship between organizational culture and teacher work productivity, so to improve teacher work productivity can be done by improving organizational culture" [28].

To find out the magnitude of the influence of organizational atmosphere and organizational culture simultaneously on work productivity can be seen from the value of $t$ in the Coefficients table with the criteria for testing the significance level of less than 0.05 . Based on the t-test results table, it is obtained that the t-count value of the organizational atmosphere and organizational culture simultaneously has a value of $p$-value $0,000<0.05$, which means that it is significant. Thus the organizational atmosphere and organizational culture simultaneously affect work productivity. Double linear regression equation: $\hat{\mathrm{Y}}=40.245+0.246 \mathrm{X}_{1}+0.148 \mathrm{X}_{2}$. The equation states that each addition of organizational atmosphere and organizational culture by 1 will increase work productivity by 0.246 and 0.148 , meaning that each increase in the organizational atmosphere and organizational culture by 1 , will increase work productivity by 0.246 and 0.148 .

Furthermore, to determine the magnitude of the influence of the organizational atmosphere and organizational culture together (simultaneously) on work productivity can be seen from the calculation of the coefficient of determination. $\mathrm{R}$ Square of 0.103 , this means that the coefficient is terminated $(\mathrm{KD})=\mathrm{R}^{2} \mathrm{X} 100 \%$ or $0.103 \times 100 \%=10.3 \%$ work productivity is influenced by atmosphere variables and simultaneous organizational culture, while the remaining $89.7 \%$ is influenced by other factors not researched. Partially "there is a significant simultaneous effect between independent variables consisting of work motivation, organizational culture and organizational commitment to the work productivity of lecturers and staffs" [29].

\section{CONCLUSION}

Based on the results of the study with statistical calculations assisted by the SPSS Version 22 program, it has been proven that atmosphere and organizational culture have a significant effect on work productivity, so it can be concluded that the work productivity of educational staff can be increased through improving organizational atmosphere and culture.

\section{SUGGeSTION}

Based on the results of the research, here is the suggestion: (1) The institutions should be able to give fair and proportionate appreciations/rewards to education personnel, firmly committed to encouraging staff trust. So that the working atmosphere becomes conducive. (2) The leaders pay more attention to team performance, uphold work discipline, strengthen friendship so that work ties become more intimate, work team synergy becomes better, so the organizational culture supports the improvement of work productivity.

\section{REFERENCES}

[1] P. Erwin, Peringkat universitas dunia 2020 [Online]. Retrieved from: https://tekno.tempo.co/read/1217107/peringkat-universitas-dunia-2020ui-turun-ugm-dan-itb-naik/full\&view=ok, 2019, Accessed on: 2019.

[2] Undang-undang Republik Indonesia Nomor 20 Tahun 2003 Tentang Sistem Pendidikan Nasional.

[3] A. Yusuf, "Produktivitas kerja guru ditinjau dari perilaku kepemimpinan kepala sekolah, iklim kerja organisasi sekolah, dan motivasi kerja guru di SMP negeri se-kota Semarang", Lembaran Ilmu Kependidikan, Universitas Negeri Semarang, ISSN 0216-0847, LIK, vol. 42, no. 2, pp. $107-115,2013$.

[4] S. Pratiwi, "Pengaruh motivasi, kerja dan tingkat pendidikan terhadap motivasi produktivitas kerja guru SMK saraswati Sukoharjo", Jurnal Manajemen Sumber Daya Manusia, vol. 9, no. 1, pp.21-38, 2015.

[5] R.M. Abast, "Hubungan motivasi kerja dengan produktivitas guru SMK di kota Manado", Jurnal Pendidikan Teknologi dan Kejuruan, vol. 2, no. 2, pp. 71-82, 2011.

[6] K. Davis, "Human behavior at work, organizational behavior. Seventh Edition. New York: Mc.Graw Hill, Inc., 2002, pp. 21.

[7] R. Stringer, Leadership and organizational atmosphere: The cloud chamber effect uppet sandle river. NJ Prentice Hall, 2004, pp. 130.

[8] S.P. Siagian, Kiat meningkatkan produktivitas Kerja. Jakarta: Rineka Cipta, 2011, pp. 24-63.

[9] A. Liliweri, Sosiologi dan komunikasi organisasi. Jakarta: PT Bumi Aksara, 2014, pp. 304

[10] E.K. Fremont and E.J. Rosenzweig, Organisasi dan manajemen 2 (edisi keempat). Jakarta. PT Bumi Aksara. (Versi Bahasa Indonesia), 2005, pp. 952.

[11] S.P. Robbins, Organizational behavior (10th edition). New Jersey. Prentice Hall, Inc. Indeks. (versi bahasa Indonesia), 2005, pp. 247.

[12] R. Mondy, S. Wayne, A. Arthur, and R.S. Premeux, Management, concepts, practices, and skills (Fifth ed). Massachusetts. Silmon \& Schuster, Inc., 2005, pp. 450.

[13] J. Greenberg and A.B. Robert, Behavior in organizatiom understanding and manazaging the human slide of work. Needham Height: Allyn and Bacon Inc. 2003, pp. 17.

[14] J.L. Gibson, J.M. Ivancevich, and J.H. Donnely, Organisasi (Terjemahan). Edisi Ke-Lima. Jakarta: Erlangga, 2006, pp. 17-77.

[15] E.H. Schein, Psikologi organisasi. Jakarta: Midas Surya Grafindo, 2005, pp. 116.

[16] F. Luthans, Organizational behavior. Singapore. McGraw-Hill, 2006, pp 52

[17] T. Pabundu, Budaya Organisasi dan Peningkatan kinerja perusahaan. Jakarta: PT Bumi Aksara, 2006, pp. 10.

[18] S. Sedarmayanti, Sumber daya manusia dan produktivitas kerja. Bandung: Mandar Maju, 2009, pp. 57.

[19] B. Kusriyanto, Peningkatan produktivitas karyawan. Jakarta: LPPM \& PT. Pustaka Binaan, 1993, pp. 2.

[20] D. Sunyoto, Teori, kuesioner, dan analisis data sumber daya manusia (praktik penelitian). Yogyakarta: CAPS, 2012, pp. 41.

[21] T.L. Gie, Efisiensi kerja bagi pembangunan negara. Yogyakarta, Gajah Mada University, 1998, pp. 78.

[22] M. Sinungan, Produktivitas apa dan bagaimana. Jakarta: Bumi Aksara, 2005, pp. 12-23.

[23] J. Suprihanto, Penilaian kinerja dan pengembangan karyawan. Yogyakarta: Gadjah Mada University Press, 2000, pp. 117.

[24] A.M. Budiono and S. Sugeng, Bunga rampai dan kesehatan kerja. Semarang: Badan Penerbit UNDIP, 2003, pp. 263.

[25] S.T. Mangkuprawira, Manajemen sumber daya manusia strategik. Jakarta: Ghalia Indonesia, 2003, pp. 47.

[26] H. Simamora, Manajemen sumber daya manusia. Yogyakarta: STIE YKPN. 2004, pp. 612.

[27] M. Busro, Teori-teori manajemen sumber daya manusia. Jakarta: Pranada Media Group, 2018, pp. 349-353. 
[28] A. Jakiyah, S. Sumardi, and R. Hidayat, "Peningkatan produktivitas kerja guru melalui pengembangan kepemimpinan transformasional dan budaya organisasi", Jurnal Manajemen Pendidikan, vol. 6, no. 2, pp 663-671, 2018
[29] R. Rukmini, "Pengaruh motivasi kerja, budaya organisasi dan komitmen organisasi terhadap produktivitas kerja dosen dan karyawan pada Akademi Akuntansi Surakarta”, Jurnal Akuntansi dan Pajak, vol. 15, no. 01, pp. 81-97, 2014. 